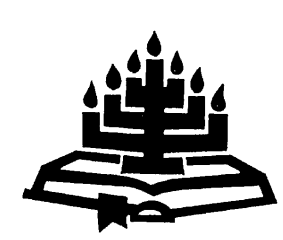

\title{
The Kingdom of God and those who have not heard the contents of Scripture ${ }^{1}$
}

\author{
M.A. Kruger \\ Researcher: School of Biblical Sciences \\ Potchefstroom University for CHE \\ POTCHEFSTROOM \\ E-mail:makruger@xsinet.co.za
}

\begin{abstract}
The Kingdom of God and those who have not heard the contents of Scripture

Article 2 of the Belgic Confession deals with the following issue: By what means does God make Himself known to us? The first part of Article 2 that echoes the teaching of Calvin via the Gallic Confession reads as follows: "We know Him [God] by two means: First by the creation, preservation and government of the universe, which is before our eyes as a most elegant book, wherein all creatures, great and small, are characters (read: letters - MAK) leading us to see clearly the invisible things of God, even his everlasting power and divinity, as the apostle Paul says (Rom. 1:20). All which things are sufficient to convince men and leave them without excuse."

This article of 1561 agrees with Calvin's Institutes of $1559(1, \mathrm{~V}, 1)$ and the early Reformed Confessions before the Canons of Dordt (1618-1619).

It seems as though, after Calvin, a doctrine of insufficiency regarding this first means of revelation gradually developed. In the Westminster Confession of 1647 this means of understanding God's revelation (i.e by receiving God's communication through the creation, preservation and government of the universe) was explicitly interpreted as insufficient. Man's inherent ability to know God by means of his own mental capacity, the so-called light of nature, that remained after the Fall, was also regarded as insufficient.
\end{abstract}

1 A reworked version of a paper originally delivered at an international conference on "The Kingdom of God" - Aug. 2000, Potchefstroom. 
The issue of whether the interpretation of Article $2 A$ had not been changed in the first century after Calvin should therefore be seriously considered by Reformed churches.

Furthermore, the church of today, situated in a world that experiences such phenomenal scientific and technological changes, should ask what relevance Article $2 A$ of the the Belgic Confession has for the church and the world.

\section{Opsomming}

Die koninkryk van God en diegene wat nog nie die inhoud van die Skrif gehoor het nie

Die Nederlandse Geloofsbelydenis lui soos volg in Artikel 2A: "Ons ken Hom [God] deur twee middele: Ten eerste deur middel van die skepping, onderhouding en regering van die hele wêreld. Dit is immers voor ons oë soos 'n mooi boek waarin alle skepsels, groot en klein, die letters is wat ons die onsigbare dinge van God, naamlik sy ewige krag en goddelikheid, duidelik laat sien, soos die apostel Paulus sê (Rom. 1:20). Al die dinge is genoegsaam om die mense te oortuig en hulle alle verontskuldiging te ontneem."

Hierdie artikel van 1561 stem ooreen met Calvyn se Institusie van $1559(1, V, 1)$ en die vroeë Gereformeerde Konfessies voor die Dordtse Leerreëls (1618-1619).

Dit skyn asof, ná die tyd van Calvyn, die leer van die ongenoegsaamheid van hierdie eerste wyse van Godsopenbaring (naamlik deur die ontvang van God se kommunikasie deur die skepping, onderhouding en regering van alle dinge) geleidelik ontwikkel het. In die Westminster Konfessie van 1647 is hierdie openbaringswyse van God eksplisiet beskryf as ongenoegsaam. So ook is die konsep van die lig van die natuur, dit is die menslike vermoë om God te ken, en wat na die sondeval in die mens oorgebly het, as ongenoegsaam beskou.

Die vraag moet aan gereformeerde kerke gestel word of die verklaring van Artikel $2 A$ nie verander het in die eerste eeu na Calvyn nie. Verder moet die kerk van vandag ook midde in 'n wêreld wat sulke fenomenale wetenskaplike en tegnologiese veranderinge beleef, vra wat die betekenis van hierdie artikel vir die kerk en die wêreld is.

\section{Introduction}

The issue argued in this article is the following: Has the Reformed tradition followed in the footsteps of Calvin and the Reformation in understanding the revelation of God in the creation, preservation and government of the universe? 
This article attempts to evaluate the Reformed tradition after Calvin with regard to the understanding of the Belgic Confession, Article 2A. The issue discussed include the following questions: Is the history of the interpretation as well as the dogmatic evaluation of this confessional article not perhaps clouded by the influence of political aspirations and anti- and pro-Roman-Catholic tensions? What was the result of the Presbyterian (also Puritan) versus Episcopalian controversies and the Arminian and anti-Arminian legacies? What was the effect of the struggle between Presbyterians and Puritans on the one hand, and, on the other hand, the attempts of the English rulers to appease Roman Catholicism?

However, the stimulus to investigate the Reformed heritage after Calvin, was not the historical process as such in first instance, but the seeming contradiction between the interpretation of the mentioned confessional article and its face value. My assumption that the interpretation of this article was (is) inaccurate, found a solid foundation when I exegeted Romans I. Only afterwards did I investigate how the Reformed tradition has seemingly deviated from the correct understanding of Romans 1.

The method applied in this article will be to analyse the exegetical results of a study of Romans and then to proceed to give an interpretation of Article $2 \mathrm{~A}$, as it was probably understood by Calvin and during the time of the Reformation. The way the Reformed tradition has dealt with Article 2 of the Belgic Confession will consequently be scrutinized. In conclusion the history (political and ecclesiastical) will be briefly looked at to ascertain where interpretations may have gone wrong.

It is of the utmost importance that the church will reflect on the correct Scriptural view (in contrast to the views of main-line, non-Christian religions, and of people who have not yet have access to Scripture) and to evaluate these views in relation to constant discoveries of new wonders in God's creation.

\section{Understanding Romans}

Biblical literature in the Reformed tradition after Calvin often shows a tendency to use parts of Romans 1:18-23 and 10:14-18 as dicta probantia. This way of dealing with Scripture has been repeatedly warned against (eg. at the World Conference of Reformed Churches; see Gaffin, 1994:23). Very often references to the above-mentioned sections of Romans present a distorted view of the passages and even arrive at conclusions directly opposite to what Paul taught. In Romans 10:14-18 the possibility of a distorted interpretation is even greater than in Romans 1:18-23, mainly because the passage is often not studied 
within the larger unit of Romans 9:30-10:21, and also because the careful selection of Greek words is not always noted.

Although one should not have too high an esteem of contemporary scholarly work, one should, on the other hand, acknowledge that progress in the study of structure and structural markers, as well as other modern approaches, has helped us greatly to understand Paul's aim better (Kruger, 2000:1-5).

It is impossible to deal with a number of Scriptural passages, or even with Romans as a complete document in this article. I shall thus only refer to the conclusion at which Paul arrives in Romans 1:18-23, and which is corroborated by 9:30-10:21. Romans 1:18-23 states that there are certain people who suppress God's truth. This truth is further described as that part of God's revelation that can be grasped and understood: God's revelation evident in the creation, preservation and government of the universe, referred to in the Belgic Confession, Article 2A. Elsewhere Paul equates truth with gospel. In Colossians 1:5 this equation is very explicit: God's revelation always implies gospel. God's wrath is directed against those who suppress his truth, because this truth (His revelation) is sufficient to bring them to a stage where they are able to glorify and thank God. These people, however, prefer not to do it. Romans 9:30-10:21 comes to the same conclusion about the Jews who rejected God's truth and ultimately rejected Christ (see Kruger, 1988:8197 and Calvin's Institutes [1, IV, 2 and 3]).

In interpreting Romans 1:18-23 many theologians often find a basis for accepting God's "general revelation". While the distinction between the so-called general and the special revelation is widely accepted as illustrated in the book Through no fault of their own (Crockett, 1991) there is no sufficient exegetical proof for this distinction in the abovementioned passage from Romans. In Romans 1:18-23 God is indicated as the God of love and personal involvement for the sake of salvation of everyone.

\section{Understanding the Belgic Confession, Article 2A}

Since the seventeenth century extensive discussion about divine revelation and how we come to know God has centred in the understanding of the Belgic Confession, Article 2A, dealing with God's revelation as received via the creation, preservation and government of the universe. There seems to be a difference between the simple meaning of the words of the Article and the interpretation given by later post-Reformational dogmaticians. This difference in interpretation implies that Guido de Brès and Calvin understood the issue of revelation 
differently than for instance Bavinck, Polman and Berkouwer. The discussion of Article 2A by these theologians indicates an uneasiness and even a tension between the Article and the interpretation that was current at the time when they wrote their views and explanations of this article.

Article 2A of the the Belgic Confession deals with the subject of the means by which God is known to us. The introductory sentence is: "We know Him by two means ..." This sentence is followed by the description of the first means by which we know God:

First by the creation, preservation and government of the universe, which is before our eyes as a most elegant book, wherein all creatures, great and small, are characters (read: letters - MAK) leading us to see clearly the invisible things of God, even his everlating power and divinity, as the apostle Paul says (Rom. 1:20). All which things are sufficient to convince men and leave them without excuse.

(The translation of divinity with Godhead instead is to be preferred MAK.)

To understand the words of the Article one should follow sound hermeneutical rules. The context of the Article should thus receive due attention and the meanings of words derived from the same root should not be clouded by extra-contextual explanations. This can happen in the case of know and its derivatives: the link with the phrase what can be known from Romans 1:19 should be maintained. Furthermore, it can not be regarded as sound hermeneutics to underplay words like sufficient to convince and to ignore the link this phrase has with the central theme of the confessional article, that is "How do we know God?" Another hermeneutical rule is that no word should be inserted as an explanatory aid when it originally was obviously not intended thus. This kind of insertion can take place for instance, when the effect of this first means of revelation is explained as "only to leave them without excuse". This insertion can probably be ascribed to the influence of traditional postReformational dogmatics.

The aim of Article $2 \mathrm{~A}$ is obviously to teach how we can know the one God whom we confess in Article 1. This enabling to know God is in reality effected by God revealing Himself to us. In first instance God's continuous coming to us, and to humankind in totality, is stressed. Then the more clear and explicit revelation in Scripture is named. Both types of revelation imply God's personal involvement with every human being so that everyone is able to know Him and be saved. The grace of God in communicating with mankind through God's revelation in the creation, 
preservation and government of the universe is already sufficient to bring man to trust, to glorify and to thank God. Apart from this revelation, God's grace, as is evident when studying Scripture, is proof of His abundant love to a fallen and rebellious world.

The Gallic Confession (1559) and the Hungarian Confession (1562) are in agreement with this interpretation of the the Belgic Confession (Berkouwer, 1951:222).

\section{Calvin's teaching about God's revelation by means of the creation, preservation and government of the universe}

When interpreting Calvin's views one should constantly keep in mind that he was well-versed in Christian humanistic philosophy (Partee, 1977:212). It is most probably due to this expertise that he often speaks of man in a philosophic-universalistic way, instead of expressing himself more precisely, for instance in his commentary on Romans 1:21. He sometimes seems to generalise without intending the generalisation to be understood as absolute and exclusive. Furthermore, it should also be taken into account that Calvin had already written his commentary on Romans in 1539. His commentary should therefore be seen in the light of the final edition of the Institutes of 1559, because during the interim period his theological thinking had developed. We should also be careful to note when Calvin deals directly with God's revelation in the creation, preservation and government of the universe, and when he touches on this revelation only while he is busy with some other topic that he focuses on at that moment.

Thus, for instance, the concept of insufficiency as stated in Calvin's commentary on Acts 14:17 must be understood in the light of what he says about Romans 1:20 where he speaks of the sufficiency of God's revelation in the creation, preservation and government of the universe. The insufficiency referred to is not that of God's revelation, but the insuffiency due to man's blindness to understand this revelation.

When Calvin comments that our knowledge (note: not God's revelation, but our knowledge) of God is insufficient, both words, our and knowledge, should receive careful attention.

Let us scrutinize the word knowledge first. At this point in his commentary Calvin does not disclose anything about revelation but rather indicates what we, due to our sin, has made of God's revelation.

Secondly the word our should by interpreted in context: Calvin obviously speaks from a position of solidarity with those who suppress God's truth. 
From his philosophical view, and most probably from his general observation of mankind, he includes himself in this situation. However, his intention was never to be exclusive, to say that no person can know God through positively accepting His revelation in the creation, preservation and government of the universe.

What has been said above is clear from two explicit statements about the sufficiency of this first means of God's revelation.

The first statement is in Calvin's commentary on Romans 1:20:

Yet let this difference be remembered, that the manifestation of God, by which he makes his glory known in his creation, is, with regard to the light itself sufficiently clear; but that on account of our blindness it is not found to be sufficient (Calvin, 1959:71).

Calvin clearly speaks from the viewpoint of those who have rejected God's truth (Rom. 1:18).

The second sure pillar for understanding Calvin's train of thought is found in his Institutes ( I, V, 1) where he says:

The final goal of the blessed life, moreover, rests in the knowledge of God (cf. John 17:3). Lest anyone, then, be excluded from access to happiness, he not only sowed in men's minds the seed of religion ... but revealed himself and daily discloses himself in the whole workmanship of the universe. (See also Institutes I, V, 10 - MAK.)

One should remember that Calvin, at this point of his argument, focuses on the topic of God's revelation in the creation, preservation and government of the universe.

The agreement between Calvin and Article 2A of the Belgic Confession is noteworthy. Both speak about knowledge and both regard this knowledge as a basis for salvation. We should also pay attention to two other phrases used by Calvin, because in the Reformed tradition confusion about the implicit meanings of these phrases, that is, seed of religion and Scripture which serves as spectacles have been evident.

What then is the seed of religion (sensus divinitatis or semen religionis)? Calvin states that God implanted this seed into all human beings (Institutes I, III, 1). This seed prevents mankind from taking refuge in the pretence of ignorance. As regards man himself, not even one in a hundred is met who fosters this seed, not even one in whom it ripens and even less do people bear fruit in season. With the aid of this seed of religion nobody can know God. However, when God's "words", his revelation via the universe touches man, a fusion of the seed of religion 
and the knowledge of God coming from the universe can result in a saving knowledge.

In Reformed circles Calvin's metaphor of Scripture as spectacles that enable us to understand Gods' revelation in the creation, preservation and government of the universe (better) is often misinterpreted. Calvin does not say that without Scripture we cannot acquire a saving knowledge via God's revelation in the universe, but Calvin stresses that Scripture is like spectacles through which we can see clearer and more fully who God is and how we should love Him. Thus God's plan of salvation for man is clear in Scripture, while his revelation in the universe only deepens our trust in this God who reveals Himself in this way.

\section{The period after Calvin}

Calvin took a firm stance on the Scriptural teaching of election and God's sovereignty. He did not try to reason in a so-called logical way beyond the teaching of Scripture, and acknowledged the limits of our understanding (cf. Paul in Romans 9:20-21). However, after Calvin's death Beza and others began to work out the concept of predestination as a closed system in the dogma of supra-lapsarianism (Walker et al., 1997:539). This interpretation of predestination as a closed system could have been caused by a strong Aristotelian influence on Beza (Dowey, 1964:561). Calvin regarded Plato as the greatest philosopher among the ancient philosophers (Institutes I, V, 11). Arminius, who was not an unconditional follower of Calvin, came into contact with Beza. Arminius was more inclined to the humanistic view of regarding man as not totally depraved. Opposed to the closed system about predestination, he thought in a more humanistic, lenient and liberal way about fallen man. This shift in emphasis brought about a clash between the Arminians and the traditional Calvinists. In the end, although Arminius was wrong, the anti-Arminians reacted too strongly, especially in Scotland and England (see 6).

Neither Calvin nor Guido de Brès, nor those who accepted the Confessio Belgicana (1559) and the Hungarian Confession ever considered the possibility of a natural religion or a natural theology. They, however, accepted God's sovereignty to reveal Himself in two ways, and they also accepted God's great love in coming to man, notwithstanding the fact that man rejected God. They emphasised that God takes the initiative in coming to man and that God effects man's salvation; man himself cannot know God with the inherent gifts that remained part of him after the Fall.

In the next section the overreaction in Scotland and England to the mentioned view will briefly be dealt with. 


\section{The Westminster Confession and its roots}

The struggle against Arminius had its influence - also in Great Britain. Not only were representatives from England and Scotland present at the Dordrecht Synod, but more liberal-minded English theologians thought that the conclusions of Dordt were rigid. Consequently, sympathy with Arminius and his followers was evident (Van den Berg, 1988:5-8). After 1620 an anti-Calvinistic reaction emerged in England (Van den Berg, 1988:6). This reaction was not fully Arminian in character, although the reaction was more sympathetically inclined towards Arminius (Van den Berg, 1988:6). In this period pro-Arminian sympathies were regarded as anti-Puritan (Van den Berg, 1988:6). It seems as if the reaction of the Puritans, and their influence in Scotland and England could have stimulated the harsher formulation of the Westminster Confession in its first article. In this Confession it is initially expressed in direct words that the light of nature, as well as God's revelation in the creation, preservation and government of the universe are insufficient to supply enough knowledge to bring man to salvation.

Another factor may have contributed to the acceptance of the concept of insufficiency included in the Westminster Confession. During the struggle at the beginning of the seventeenth century in England a fierce reaction constantly erupted against anything that pointed to popery. This reaction could have stimulated a sola scriptura point of view that was more radical than Calvin and other Reformers believed (Shaw, 1974:2-9).

In 1560 Scotland was declared a Protestant country (Fraser, 1974:24). At this stage the majority of the people were still Roman Catholic (1974:24). Furthermore, right from the beginning of the Reformation in Scotland a struggle between the Episcopalians and the Presbyterians was evident (Fraser, 1974:24). The Presbyterians feared that having bishops would again stimulate Roman Catholicism. Therefore they emphasised the idea of "the Scriptures only" and accepted as permanent offices only those that Calvin accepted. They also protested fiercely against the re-introduction of certain Roman-Catholic ceremonies (Fraser, 1974:181). King James VI of Scotland (James I of England) received a thorough Calvinist education and was well trained in a number of languages and the Scriptures. He succeeded with great difficulty in maintaining a balance between the Episcopalians and the Presbyterians. When he became king of England as well, James sought to improve relations with Roman Catholics for political purposes and established closer relations with the king of Spain (Fraser, 1974:202). His successor to the throne of England and Scotland, Charles I, who as a prince already had a relationship with the Spanish Roman-Catholic princess, Infanta Maria, made the mistake of favouring the Episcopalians 
in Scotland to such an extent that civil war broke out when he succeeded James in 1625 (Ashley, 1964:304). Charles married Henrietta, daughter of Marie de Medici, a devoted Roman Catholic (Leonard, 1967:297). Charles's attitude brought about fierce reaction from the Puritans and Presbyterians in Scotland and England. His rule from 1625-1649 was characterised by a continuous conflict between Anglicanism and Puritanism (Leonard, 1967:296). During the time that the Long Parliament gathered (1643 to 1646) the acting parliamentarians were predominantly in favour of the Puritans and Presbyterians (Ashley, 1964:305).

With this threat of Roman Catholicism, the Puritans and Presbyterians over-emphasised the Scriptures to such an extent that the ideal of sola scriptura received an additional dimension. Originally the inherent meaning of the two words implied resistance against Roman-Catholic tradition, hierarchy, papal power and the superiority of the Church to interpret Scripture. What was subsequently inscribed into the first article of the Westminster Confession was an addition that implied that only God's revelation by Scripture can lead to salvation and not also God's revelation in the creation, preservation and government of the universe. This was a radicalisation of what Calvin taught, as well as of the Gallic Confession and the Hungarian Confession.

Barrett $(2000$, III) even goes as far as to state that issues of temporal power, not theology, often control developments in the life of the Church.

\section{Bavinck's views}

Bavinck serves as an example of later Reformed theologians who accepted the insufficiency of God's revelation in the creation, preservation and government of the universe

The choice of Bavinck's view (1826-1909) as an example of a theologian who taught the insufficiency of the so-called general revelation is justified by the following:

- He explains his reasons for accepting the concept of general revelation very distinctly (Bavinck, 1928:284-285).

- His views have exercised great influence in South African Reformed churches.

Bavinck (1928:278) remarks that all revelation is supra-natural, for it is supra-natural in origin. According to Bavinck (1928:281) the fact that, after the Fall, sin became part of a broken creational reality, did not change the nature of God's revelation and God did not withdraw Himself 
from His creation. Bavinck (1928:281) emphasises that, what he calls revelatio generalis, is taught throughout Scripture. According to Bavinck, this Scriptural revelation is general in nature, in itself recognisable and every human being is able to understand the general revelation. Both nature and history are "the book" of God's almighty power and wisdom, of his kindness and justice (Bavinck, 1928:282). Heathen religions originated and rest on this revelation, but also upon remnants of elements of tradition of what Bavinck (1928:282-283) calls God's special revelation evident since the beginning of humanity.

Notwithstanding Bavinck's very positive judgement of God's revelation in the creation, preservation and government of the universe (nature and history), he deems this revelation as insufficient because of three reasons (1928:283-286).

- This kind of revelation leaves us without knowledge about the person of Christ, who is the only way to the Father.

- This knowledge is not only limited but is also insecure.

- The insufficiency is demonstrated by the fact that no nation has ever been satisfied with the concept of religio naturalis.

Contra the first argument in favour of insufficiency it should be stated that Bavinck in this respect overrates knowledge as an element of faith, and underestimates trust. In comparison to what Jesus taught, the overrating of knowledge can be illustrated. When Jesus calls the weary and burdened people to Him, it is primarily a call to trust Him and not to rely on knowledge and legalism as the Pharisees and Scribes demanded (Matt. 11:28-30). Bavinck's argument is also contrary to the words of Matthew 5:3 that the poor in spirit are the inheritants of the Kingdom of God. Interpreters are unanimous that this qualification implies unconditional trust in the person of Jesus Christ as Saviour and does not refer to intellectual capacity. Childlike trust in God also implies faith in Christ in whom we were saved even before the creation of the world. Some interpreters and scholars call people who come to faith as a result of God's revelation in the creation, preservation and government of the universe "implicit Christians" (Crockett \& Sigountos, 1991:260).

With regard to the nature and extent of knowledge "necessary" to be an "implicit Christian" the following questions come to the fore: How much knowledge (cf. Romans 1:19, 21) is necessary to bring one to a firm trust, and thus to a saving faith, in God? Should knowledge of the Triune God, for instance, always be present with the same clarity as revealed in later revelationary history? Should this knowledge include acquaintanceship with Christ's suffering and deeds? Is it possible that people can 
react obediently in an act of submission to the God who reveals Himself in the creation, preservation and government of the universe? Is the emphasis on knowledge not a contradiction of grace (Rom. 4:16)? Submission to God also implies submission to Christ. Oscar Cullman (1980:321) rightly remarks that wherever God has revealed Himself, Christ is present. Old Testament-Israel knew more than the Gentiles about the promised Christ, but much less than the New Testament reveals.

The post-Reformation did not escape the influence of Rationalism and the Enlightenment.

It can also be argued that Bavinck's second argument confuses two elements: On the one hand it is implied that God's revelation is pure and sufficient in itself to lead to trust in Him, and on the other hand, man's sinfulness and obstinacy is stressed. Calvin (1959:71) states that it is due to man's sin that the extent of God's revelation in creation is insufficient to convince man of God's existence, and not that God's revelation in itself is insufficient. Furthermore, the emphasis is not on man's inherent ability to know God - knowledge that results in salvation - but on God's coming to man. If it is true that man cannot know God via the so-called general revelation, the same argument should also be true about Scripture, because it is not by man's doing that he is saved mankind is saved by the loving grace of God.

In the third place Bavinck makes a transition in his argument that can probably be regarded as an incorrect conclusion: The focus of his argument shifts from revelatio naturalis to religio naturalis. Revelation, however, is an act, a gift from God. The religio naturalis, on the other hand, refers to what man (sometimes) makes of this revelation.

Bavinck values revelatio generalis very highly, but in the light of what Scripture teaches, especially in Romans, his arguments in favour of the insufficiency of the so-called general revelation are not convincing: Reasons that can be attributed to Bavinck's inconvincing arguments can possibly be ascribed to the following:

- The views that developed within Reformed churches in the Netherlands and Great-Britain and that were later also inherited in SouthAfrican Reformed churches and elsewhere in the world was an overreaction to the ideas of Arminianism and the threatening return of Roman Catholicism.

- An over-emphasis of Scripture, not as the means of revelation which can lead to salvation, but as the only means of revelation which can lead to salvation, has developed after the Reformation. 


\section{Arminius, natural religion and natural" revelation, the"light of nature" and Karl Barth}

The Reformed churches' deviation in the interpretation of the so-called insufficiency of God's revelation in the creation, preservation and government of the universe, and the resulting misinterpretation of the Belgic Confession, Article 2A, as well as of Romans 1:18-23, were established long before the time of Karl Barth. The foundation for this possible misinterpretation was laid earlier and the turn came soon after Calvin. This view of the insuffiency of the general revelation gained momentum during the struggle against Arminius and the Remonstrants and the Presbyterian-Puritan reaction against Roman-Catholic resurgence. Eventually the concept of the insufficiency was made part of Article 1 of the Westminster Confession.

The struggle of the Arminians in both England and the Netherlands was directed against the Reformed doctrine of the total depravity of fallen man and man's inability to reach out to God by means of his inherent abilities still present after the Fall. This struggle, however, then became intertwined with the struggle against the Roman-Catholic doctrine of natural religion. This doctrine ascribes to man the ability to know God by means of his mental faculties enabling him to deduce certain general principles relating to God's revelation in the creation, preservation and government of the universe (often called the revelation in nature). According to this view the emphasis is not not on God who brings about man's salvation, but on man's assumed ability and mental faculties to know God.

Karl Barth reacted strongly against the first part of the Belgic Confession, Article 2. According to Barth the Reformers did not formulate a clear-cut doctrine about two possible sources of revelation. Furthermore, he said that incorporating this article into a sound confession created the possibility of natural theology and natural religion (Barth, 1940:140).

Barth was entangled in the problems of his own time and probably did not have enough objectiveness to compare his time with that of the Reformers. Barth criticized the growing influence of upcoming German National Socialism and he accused so-called Christians who supported it as claiming it to be a new divine revelation (Barth, 1939:31; 22-28). This tendency made Bavinck acutely aware of the threat and detrimental influence of natural religion. He also noticed that some German theologians again founded their views to support National Socialism on natural theology and natural religion, and not on the Bible (Berkouwer, 1951:221). 
As recently as January 2000 the post-Reformational dogmatical tradition in South Africa still endorsed a view which boils down to an assumed synonymy between the implied meanings of the concepts natural light and revelation in the creation, preservation and government of the universe. The accepted interpretation was rejected with an appeal to a so-called agreed interpretation which points to nothing less than a postReformational distortion of the Canons of Dordt and the Belgic Confession, Article 2A (GKSA, 2000:53; 60-61). This interpretational confusion of "revelation in nature" with "light of nature" seems to have been a perilous development in post-Reformational theology. This development clashes with the Reformed Confessions and does not reveal a true understanding of what was at stake during the controversy with Arminius.

The idea of fallen man's total inability to know God by means of his remaining mental faculties after the Fall, was transferred via state and church politics, and via theological reflection to the concept of the insufficiency of God's revelation. A trend to diminish the importance of God's seeking love for his highest creature, man, thus established itself in post-Reformational theology.

\section{Conclusion}

The basis for the sufficiency of the revelation in God's creation, preservation and government of the universe - revelation that can lead man to salvation - is founded firmly in Romans 1:18-23.

An incorrect interpretation of the Belgic Confession, Article $2 \mathrm{~A}$ and of Romans 1:18-23 (and also 9:30-10:21) is a widespread phenomenon in Reformed churches. This interpretation has brought about an incorrect view of the relationship between God and the church, as well as between God and those who have not heard the contents of Scripture. An acceptance of the alternative interpretation that has been given above, emphasizes God's mercy and his love to a much greater extent and enables us to avoid two extremes: general salvation on the one hand, and on the other hand, a general condemnation of those who have not yet acquired a knowledge of Scripture. In today's world where nations are so closely interdependent and where mission work by all denominations must still be a high priority - as it was for Paul who wrote Romans - this view is of the utmost importance. The belief that God's revelation in the creation, preservation and government of the universe is sufficient for man's salvation, should not be an obstacle to do missionary work. On the contrary, this point of view could be an important and positive stimulant to proclaim God's love in Jesus Christ to the world. 
God's voice as observed in scientific discoveries and progress of today, as well as in what takes place among nations, will also be heard with more alert ears when we acknowledge that He still speaks to all of us by means of the surrounding creation, and the preservation and government of the universe. The publication of Du Toit's Nature, God and humanity (1996) is an example of the ongoing struggle to understand the nature of God's communication with humankind, to comprehend His presence and acts in the surrounding creation. Such attempts should also be made by Reformed churches, accepting the basis of Scripture as our authoritative source.

\section{Bibliography}

ASHLEY, M.P. 1964. Charles I of England. (In Encyclopedia Brittanica 5. London : Enclycopedia Brittanica. p. 304-307.)

BARRETT, P. 2000. Science and theology since Copernicus. Pretoria : University of South Africa.

BARTH, K. 1939. The church and the political problem of our day. New York : Scribner's Sons.

BARTH, K. 1940. Kirchliche Dogmatik II, I. Zollikon : Verlag der Evangelischen Buchhandlung.

BAVINCK, H. 1928. Gereformeerde Dogmatiek. Eerste deel. Kampen : Kok.

BERKOUWER, G.C. 1951. De algemene openbaring. Kampen : Kok.

CALVIN, J. 1957. Commentary on the Acts of the Apostles. Volume 2. Edited from the original translation of Christopher Fetherstone, student in Divinity, by Henry Beveridge, Esq. Grand Rapids : Eerdmans.

CALVIN, J. 1959. Commentaries on the Epistle of Paul the apostle to the Romans. Translated and edited by the Rev. John Owen. Grand Rapids : Eerdmans.

CALVIN, J. 1962. Institutes of the Christian religion by John Calvin; a new translation by $\mathrm{H}$. Beveridge. London : Clarke.

CALVIJN, J. 1956. Institutie of onderwijsing in de Christelijke godsdienst I. Vertaald door A. Sizoo. Delft : Meinema.

CALVYN, J. 1984. Institusie van die Christelike godsdiens. Vertaal deur H.W. Simpson. Potchefstroom : Calvyn Jubileum Boekefonds.

CROCKETT, W.V. \& SIGOUNTOS, J.G., eds. 1991. Through no fault of their own. Grand Rapids : Baker Book House.

CULLMAN, O. 1980. The Christology of the New Testament. Translated from the German by Shirley C. Guthrie and C.A.M. Hall. Norwich : SCM.

DOWEY, E.A. 1964. Beza, Theodore. (In Encyclopedia Brittanica 3. London : Encyclopedia Brittanica. p. 561.)

DU TOIT, C.W., ed. 1996. Nature, God and humanity. Proceedings of the third seminar of the South African Science and Religion Forum (SASRF) of the Research Institute for Theology and Religion held at Unisa on 1 \& 2 June 1995. Pretoria : Unisa.

FRASER, A. 1974. King James VI of Scotland and King James I of England. London : Weidenfeld \& Nicolson.

GAFFIN, R.B. Jr. 1994. The vitality of Reformed dogmatics. (In Batteau, J.M. et al., ed. The vitality of Reformed theology. Kampen : Kok. p. 16-50.) 


\section{GKSA}

Institutes

See Reformed Churches in South Africa

See Calvin, 1956; 1962; 1984.

KRUGER, M.A. 1988. Naby jou is die Woord! Romeine 10:8. (In Coetzee, J.C., red. Koninkryk, Gees en Woord. Pretoria : N.G. Kerkboekhandel. p. 81-97.)

KRUGER, M.A. 2000. Romans. Colesberg : M.A. Kruger.

LEONARD, E.G. 1967. A history of Protestantism. Bristol : Nelson.

PARTEE, C. 1977. Calvin and classical philosophy. Leiden : Brill.

REFORMED CHURCHES IN SOUTH AFRICA. 2000. Handelinge van die sewe-enveertigste Nasionale Sinode te Potchefstroom op 10 Januarie 2000 en volgende dae. Potchefstroom : Administratiewe Buro.

SHAW, W.A. 1974. A history of the English church, during the civil wars and under the Commonwealth. New York : Burt Franklin Reprints.

VAN DEN BERG, J. 1988. Dordt in de weegschaal. Leiden : Universiteit van Leiden. WALKER, W. 1997. A history of the Christian church. 4th ed. Edinburgh : Clark.

\section{Key concepts:}

Belgic Confession, Article 2A

insufficiency of revelation

natural theology and natural religion

post-Reformational deviation

revelation: two means of

\section{Kernbegrippe:}

na-Reformatoriese afwyking

natuurlike teologie en natuurlike religie

Nederlandse Geloofsbelydenis, Artikel 2A

ongenoegsaamheid van die openbaring

openbaring: twee maniere van 